\title{
Effect of Seasonal Variation on the Persistence and Dissipation Behaviour of the Herbicide Mixture of Fomesafen + Quizalofop-Ethyl in Tropical Soybean Agroecosystem and Safety Risk Assessment
}

\section{Sushovan Das}

Bidhan Chandra Krishi Viswa Vidyalaya

Debasish Singha

Bidhan Chandra Krishi Viswa Vidyalaya

Arnab Kundu

Bidhan Chandra Krishi Viswa Vidyalaya

\section{Sandip Mondal}

ISI: Indian Statistical Institute

Abhishek Kundu

Bidhan Chandra Krishi Viswa Vidyalaya Faculty of Agriculture

\section{Arijita Bhattacharyya}

Bidhan Chandra Krishi Viswa Vidyalaya Faculty of Agriculture

\section{Mousumi Kumar}

Rishi Bankim Chandra College

Sankhajit Roy ( $\triangle$ roysankhabckv@gmail.com )

Bidhan Chandra Krishi Viswavidyalaya: Bidhan Chandra Krishi Viswa Vidyalaya

\section{Research Article}

Keywords: Fomesafen, Quizalofop-ethyl, LC-MS/MS, GC-MS/MS, Dissipation, Dietary risk, Soil ecological risk,

Posted Date: June 7th, 2021

DOl: https://doi.org/10.21203/rs.3.rs-553013/v1

License: (9) (1) This work is licensed under a Creative Commons Attribution 4.0 International License.

Read Full License 
Effect of seasonal variation on the persistence and dissipation behaviour of the herbicide mixture of fomesafen + quizalofop-ethyl in tropical soybean agroecosystem and safety risk assessment

Sushovan Das ${ }^{\mathrm{a}}$, Debasish Singha ${ }^{\mathrm{a}}$, Arnab Kundu ${ }^{\mathrm{a}}$, Sandip Mondal ${ }^{\mathrm{b}}$, Abhishek Kundua, Arijita Bhattacharyya ${ }^{\mathrm{a}}$, Mousumi Kumarc, Sankhajit Roy ${ }^{\text {a* }}$

aDepartment of Agricultural Chemicals, Bidhan Chandra Krishi Viswavidyalaya, Mohanpur-741252, Nadia, West Bengal, India

'Indian Statistical Institute, Giridih-815301, Jharkhand, India

${ }^{\mathrm{c} R i s h i}$ Bankim Chandra College, Naihati, 24 Parganas (N), West Bengal, India

*Corresponding author - Tel: +91-7319312505; Email: roy.sankhajit@ bckv.edu.in

\section{Abstract}

Weeds are the major limiting factor for optimum soybean production in India. The herbicide mixture of fomesafen and quizalofop-ethyl provides effective control of a broad spectrum of weeds, but its fate in the tropical soybean ecosystem is unknown and also the risks involved to the consumer and the environment are still unexplored. Hence, a supervised field trial was conducted following the post-emergence application of fomesafen $12 \%+$ quizalofopethyl $3 \%$ in two consecutive seasons. The dissipation of fomesafen followed biphasic double first order in parallel kinetics, whereas quizalofop-ethyl dissipation followed first order kinetics. A significant difference in the persistence of fomesafen was observed due to seasonal variation of meteorological parameters. However, the variation was significant only in plant, but non-significant in soil, in case of quizalofop-ethyl. The overall shorter persistence of both fomesafen and quizalofop-ethyl was recorded in warmer climatic conditions of Season I than Season II. The results thus indicated that care must be taken during application of this herbicide mixture in cold climatic regions, since both the herbicides may exhibit higher stability. The absence of end-point residues at harvest concluded that the formulation is safe for application in tropical agroclimate. The low chronic dietary toxicity and low soil ecological toxicity indicated that the herbicide mixture will offer no threat against consumer health and soil ecosystem. However, there was a concern about the toxicity against soil algal population which needs to be reconfirmed by further studies.

Keywords Fomesafen; Quizalofop-ethyl; LC-MS/MS; GC-MS/MS; Dissipation; Dietary risk; Soil ecological risk

\section{Acknowledgement}



The authors are indebted to the Export Testing Laboratory (NABL accredited ISO/IEC 17025: 2005 certified),

29 30 31 32 33 34 35 36 37 38 39 40 41 42 43 44 45 46 47 48 49 50 51 52 53 54 55 


\section{Introduction}

57 Soybean (Glycine max L.) is considered as the most important seed legume, which occupies one of the largest 58 monocultures in the world. Among all other field crops, it has the highest protein content (40-42\%), which is a good substitute of animal protein also and the second highest oil content (18-22\%) after groundnut. However, soybean

60 production in India is severely affected by a number of monocotyledonous and dicotyledonous weeds, resulting in 61 almost 50-76\% yield reduction (Gharde et al. 2018). To compensate for such a huge yield loss, the herbicide mixture

62 of fomesafen and quizalofop-ethyl has been introduced under the soybean cultivation in India. The mixture 63 formulation (fomesafen 12\%+quizalofop-ethyl 3\%) controls a broad spectrum of weeds due to multiple modes of 64 action. Fomesafen is a contact herbicide of the nitrodiphenyl ether chemical class. It controls broad leaf weeds by 65 inhibiting the enzyme protoporphyrinogen oxidase (Alves et al. 2018). Quizalofop-ethyl is a systemic post66 emergence herbicide of the aryloxy phenoxy propionate chemical family, which controls both annual and perennial 67 grasses by inhibiting the enzyme acetyl coenzyme A carboxylase (Janaki et al. 2018). Pesticide dissipation expresses a complex correlation with climate, since numerous interacting factors are involved. Meteorological parameters in totality determine the environmental concentration of pesticides by 70 regulating their rate of degradation (Delcour et al. 2015). Besides, climate change is reported to alter the 71 effectiveness and persistence of pesticides (Rhodes and McCarl 2020), often necessitating an increased pesticide application (Noyes et al. 2009). Therefore, conducting dissipation experiments under varying climatic conditions is

73 necessary to predict the fate of pesticides accurately. This is extremely important especially for herbicides, since

74 unlike other agrochemicals they are intended to persist longer in environment and change in climate thus tends to 75 aggravate not only the risk of environmental contamination but also the detrimental effect induced by the herbicides 76 on soil dwelling organisms. Again, the post-emergence herbicides may also contaminate the existing crop in field, 77 making it unfit for domestic consumption as well as for export. Therefore, assessing the risk involved due to field 78 application of herbicides is necessary to ensure the food and environmental safety. However, no information is 79 available regarding the fate of the aforesaid herbicide mixture in soybean and its impact on dietary as well as soil 80 ecological risk. 
Therefore, the objectives of the current research are to assess the dissipation dynamics of the herbicide mixture (fomesafen $12 \%+$ quizalofop-ethyl $3 \%$ ) in soybean and the impact of seasonal variation on its persistence.

83 Besides, the risks involved towards soil ecological environment and consumer health are also evaluated.

\section{$84 \quad$ Material and methods}

\section{Chemicals and reagents}

86 The analytical standards of fomesafen and quizalofop-ethyl of $>98 \%$ purity and their commercial formulation were

87 supplied by Crystal Crop Protection Pvt. Ltd., India. Organic solvents were purchased from J.T.Baker, USA and the salts of ACS grade were procured from Merck Life Sciences Pvt. Ltd, Germany. The dispersive clean up sorbents viz. Primary Secondary Amine (PSA) and $\mathrm{C}_{18}$ were purchased from Agilent Technologies, USA. Graphitized Carbon Black (GCB) was purchased from United Chemical Technology, Bellefonte, PA.

\section{$91 \quad$ Field experiment}

92 Experimental design

93 Supervised field trials were conducted on soybean in two consecutive seasons at Jaguli Instructional Farm of Bidhan 94 Chandra Krishi Viswavidyalaya (BCKV), Mohanpur, West Bengal, India (Latitude $22^{\circ} 93^{\prime} \mathrm{N}$, longitude $88^{\circ} 59^{\prime} \mathrm{E}$; 95 altitude $9.75 \mathrm{~m}$ ). The experimental region was constituted of new alluvial soil and the physico-chemical properties 96 are represented in Table S1. Soybean seeds (variety: Pusa 16) were sown in $5 \mathrm{~m} \times 4 \mathrm{~m}$ plots at a spacing of $30 \mathrm{~cm} \times 10$ $97 \mathrm{~cm}$. The herbicide mixture (fomesafen 12\%+quizalofop-ethyl 3\%) was applied as post-emergence on $19^{\text {th }}$ May 2017 98 in Season I and $16^{\text {th }}$ May 2018 in Season II at $225 \mathrm{~g}$ a.i. ha ${ }^{-1}$ (T1 or recommended dose) and $450 \mathrm{~g}$ a.i. ha ${ }^{-1}$ (T2 or 99 double dose) doses. Separate plots were maintained as untreated control (T3) i.e. only water spray. The experiment was designed in randomized blocks, maintaining three replicates for each treatment including control. A total of 72.3

$101 \mathrm{~mm}$ and $41.4 \mathrm{~mm}$ precipitation was recorded in Season I and II respectively, of which no rainfall was recorded up to 1026 days after application of the herbicide mixture. The meteorological parameters were monitored in the regional meteorological station of BCKV (Fig. 1). The solar intensity and UV index were obtained from the Global Land

104 Data Assimilation System and Tropospheric Emission Monitoring Internet Service, respectively (Fig. 1).

105 Sample collection 
Soybean plant and soil samples were collected at an interval of 0 ( 2 hours after application), 1, 2, 3, 4, 5, 7, 10, 13, 15, 17 and 20 days after application of the herbicide mixture. Besides, soybean oil, deoiled cake and field soil samples were collected at harvest and analyzed separately for fomesafen and quizalofop-ethyl residues.

\section{Analytical procedures of fomesafen and quizalofop-ethyl}

Extraction and clean up of soybean plant and soil

Representative $10 \mathrm{~g}$ homogenized plant and soil samples were taken separately in $50 \mathrm{~mL}$ polypropylene centrifuge tubes and $10 \mathrm{~mL}$ HPLC grade water was added. The extracting solvent was $10 \mathrm{~mL}$ acetonitrile for fomesafen, whereas quizalofop-ethyl residues were extracted with $10 \mathrm{~mL}$ acetonitrile $+1 \%$ acetic acid. A salt mixture of $1.5 \mathrm{~g}$ sodium chloride $+5 \mathrm{~g}$ magnesium sulphate was added, mixed thoroughly for two minutes and centrifuged at 5,000 rpm for 5 minutes. The supernatant $(2 \mathrm{~mL})$ of both plant and soil samples were cleaned up separately by using 50 mg PSA + 25 mg GCB + 150 mg magnesium sulphate and 25 mg PSA + 25 mg $\mathrm{C}_{18}+150$ mg magnesium sulphate clean up combinations, respectively. The extract was filtered with a $0.2 \mu$ membrane filter and analyzed in LCMS/MS for fomesafen. However, for quizalofop-ethyl, $1.5 \mathrm{~mL}$ supernatant was evaporated to dryness after clean up and reconstituted with $1.5 \mathrm{~mL}$ ethyl acetate. The extract was filtered and analyzed in GC-MS/MS.

Extraction and clean up of soybean oil

A representative $100 \mathrm{~g}$ ground soybean seed was extracted with $450 \mathrm{~mL}$ hexane in soxhlet apparatus and the solvent was evaporated at $40{ }^{\circ} \mathrm{C}$ by using a rotary vacuum evaporator to collect the oil. Representative $2 \mathrm{~g}$ oil was dissolved in $20 \mathrm{~mL}$ hexane and partitioned thrice with $3 \times 30 \mathrm{~mL}$ acetonitrile in a separatory funnel. The combined acetonitrile fraction was concentrated in rotary vacuum evaporator and reconstituted separately with acetonitrile $(2 \mathrm{~mL})$ for fomesafen and ethyl acetate $(2 \mathrm{~mL})$ for quizalofop-ethyl. Then the extracts were cleaned up by using $50 \mathrm{mg}$ PSA + $50 \mathrm{mg} \mathrm{C} 18+150 \mathrm{mg}$ magnesium sulphate and filtered with $0.2 \mu$ membrane filter before analysis.

\section{Extraction and clean up of deoiled cake}

The deoiled cake sample $(2 \mathrm{~g})$ was taken in a $50 \mathrm{~mL}$ centrifuge tube and $10 \mathrm{~mL} 5 \%$ aqueous sodium chloride solution was added. The mixture was vortexed for one minute. Then $10 \mathrm{~mL}$ acetonitrile was added and vortexed again for 2 minutes, followed by rotospin for 15 minutes at $50 \mathrm{rpm}$. The sample was centrifuged at 10,000 rpm for 5 minutes. Then $6 \mathrm{~mL}$ supernatant was evaporated to dryness and reconstituted separately with acetonitrile $(1.2 \mathrm{~mL})$ for fomesafen and ethyl acetate $(1.2 \mathrm{~mL})$ for quizalofop-ethyl. Then the extracts were cleaned up by using $50 \mathrm{mg}$ PSA $+25 \mathrm{mg} \mathrm{C} 18+150 \mathrm{mg}$ magnesium sulphate and filtered with $0.2 \mu$ membrane filter before analysis. 


\section{Instrumental Condition}

\section{LC-MS/MS}

The analysis of fomesafen was performed with Waters 2695 separation module (Waters, USA) equipped with Symmetry C18 column ( $5 \mu \mathrm{m} ; 2.1 \times 100 \mathrm{~mm})$ and Micromass Quattro Micro API mass spectrometry. Masslynx V4.1 software was used for data acquisition and quantification. The chromatographic separation was performed by using the binary mobile phase viz. mobile phase A $(5 \mathrm{mM}$ ammonium acetate $+0.1 \%$ acetic acid in water) and mobile phase $\mathrm{B}\left(5 \mathrm{mM}\right.$ ammonium acetate $+0.1 \%$ acetic acid in methanol) at a flow rate $0.3 \mathrm{~mL}$ minute ${ }^{-1}$. The gradient programming involved: $90 \% \mathrm{~A}+10 \% \mathrm{~B}$ in $0-1$ minute, $10 \% \mathrm{~A}+90 \% \mathrm{~B}$ in $1-10$ minute and $90 \% \mathrm{~A}+10 \% \mathrm{~B}$ in $10-$ 12 minute. Negative electrospray ionization with multiple reaction monitoring (MRM) scan type was used for analysis. The MRM transitions of fomesafen were: 436.98 > 195.01 (quantifier) with collision energy (CE) $41 \mathrm{eV}$; $436.98>222$ (qualifier) with CE $29 \mathrm{eV}$ and 436.98 > 285.9 (qualifier) with CE $22 \mathrm{eV}$. The other parameters were: capillary voltage $(1 \mathrm{kV})$, cone voltage $(31 \mathrm{~V})$, source temperature $\left(120^{\circ} \mathrm{C}\right)$, desolvation temperature $\left(360{ }^{\circ} \mathrm{C}\right)$, desolvation gas (nitrogen) flow $\left(650 \mathrm{~L} \mathrm{~h}^{-1}\right)$ and collision gas (argon) flow $\left(50 \mathrm{~L} \mathrm{~h}^{-1}\right)$.

\section{GC-MS/MS}

The analysis of quizalofop-ethyl was performed by GC-MS/MS (Agilent Technologies, USA), equipped with 7890A GC, 7000 MS and Masshunter B.05.00 software. GC separation was performed in HP-5 MS capillary column (30 $\mathrm{m} \times 0.250 \mathrm{~mm} \times 0.250 \mu \mathrm{m}$ ) and helium (purity $\geq 99.99 \%$ ) was used as a carrier gas at a constant flow of $1 \mathrm{~mL}^{2}$ minute $\mathrm{e}^{-}$

${ }^{1}$. Splitless injection mode was used to inject $1 \mu \mathrm{L}$ sample. A constant inlet temperature $\left(285^{\circ} \mathrm{C}\right)$ and auxiliary heater temperature $\left(280{ }^{\circ} \mathrm{C}\right)$ were maintained. The oven temperature programme involved: Ramp $1\left(150-220{ }^{\circ} \mathrm{C}\right.$, Rate: 50 ${ }^{\circ} \mathrm{C}$ minute ${ }^{-1}$, Hold: 1 minute); Ramp $2\left(220-250{ }^{\circ} \mathrm{C}\right.$, Rate: $10{ }^{\circ} \mathrm{C}$ minute ${ }^{-1}$, Hold: 2 minutes) and Ramp $3\left(250-280{ }^{\circ} \mathrm{C}\right.$, Rate: $5^{\circ} \mathrm{C}$ minute ${ }^{-1}$, Hold: 2 minutes). The mass spectrometry parameters involved electron impact (EI) ionization at $-70 \mathrm{eV}$ energy and source temperature of $230^{\circ} \mathrm{C}$. The MRM transitions of quizalofop-ethyl were: $372.1>299.3$ (quantifier) and $299.2>91.2$ (qualifier) with collision energy 10 and $25 \mathrm{eV}$, respectively.

\section{Recovery experiment}

The recovery experiment was carried out by fortifying all the substrates viz. soil, soybean plant, oil and deoiled cake at $0.01,0.05$ and $0.10 \mathrm{mg} \mathrm{kg}^{-1}$ concentration levels separately for fomesafen and quizalofop-ethyl. An eight point calibration curve involving $0.003,0.01,0.02,0.05,0.10,0.25,0.50$ and $1.0 \mathrm{mg} \mathrm{kg}^{-1}$ concentration levels was used for quantification. 


\section{Data analysis}

163 The degradation of pesticides is often reported to follow biphasic kinetics in the field (Gluhar et al. 2019).

164 Therefore, the dissipation of fomesafen and quizalofop-ethyl were determined by comparing between two kinetic 165 models as follows:

166 Single First Order (SFO): $y=a e^{-b t}$

167 Double First Order in Parallel (DFOP): $y=a e^{-b t}+c e^{-d t}$

168 Where, ' $y$ ' is the concentration $\left(\mathrm{mg} \mathrm{kg}^{-1}\right)$ at time ' $\mathrm{t}$ ' (days), ' $\mathrm{a}$ ' is the initial concentration at time $\mathrm{t}=0$ and ' $\mathrm{b}$ ' is the 169 dissipation constant $\left(\right.$ days $\left.^{-1}\right)$ in SFO. In DFOP, ' $a$ ' and ' $c$ ' are the initial concentrations for two compartments and 170 ' $b$ ' and ' $d$ ' are the respective dissipation constants. The parameters of the kinetic models were estimated by using R 171 Studio version 1.2.5042 (RStudio Team 2020) and associated package viz. mkin (Ranke 2020). The best fit model 172 was selected based on $\chi^{2}$ test as recommended by the FOCUS work group (FOCUS 2006).

\section{Safety evaluation}

174 Dietary risk assessment

175 The chronic dietary risk quotient $\left(\mathrm{RQ}_{\mathrm{d}}\right)$ was assessed as follows:

176 $\mathrm{RQ}_{\mathrm{d}}=\frac{\text { Estimated Daily Intake (EDI) }}{\text { Acceptable Daily Intake (ADI)x Average BodyWeight }}$

177 The estimated daily intake (EDI) was calculated by multiplying the residue levels of fomesafen and quizalofop-ethyl 178 in soybean plant with recommended consumption of soybean per day per person. The National Institute of Nutrition 179 reported an intake of $30 \mathrm{~g}$ and $75 \mathrm{~g}_{\text {person }}{ }^{-1}$ day $^{-1}$ of pulses for children (4-6 years) and adults (National Institute of 180 Nutrition 2011). The average body weight of an Indian child and an adult are $18 \mathrm{~kg}$ and $60 \mathrm{~kg}$ (National Institute of 181 Nutrition 2011). The acceptable daily intake (ADI) of fomesafen and quizalofop-ethyl is 0.003 and $0.0013 \mathrm{mg} \mathrm{kg}^{-1}$ 182 body weight day ${ }^{-1}$ (PPDB 2021a, b), respectively. The $\mathrm{RQ}_{\mathrm{d}}>1$ signifies high risk for consumption and vice versa.

183 Soil ecological risk assessment

184 The soil ecological risk quotient $\left(\mathrm{RQ}_{\mathrm{s}}\right)$ of both fomesafen and quizalofop-ethyl was estimated for algae, earthworm 185 and arthropods following the equation: 
187 The predicted no effect concentration (PNEC) was obtained by dividing the toxicity value of respective target organism by corresponding assessment factor which was 50 for both the cases. The risk factor is considered high if

$189 \mathrm{RQ}_{\mathrm{s}}>1$, moderate for $0.1-1$ and low for $\mathrm{RQ}_{\mathrm{s}}<0.1$ (European Communities 2003).

190 Results and discussion

191 Method validation

192 The analytical methods of fomesafen and quizalofop-ethyl were validated following the SANTE guideline (SANTE 193 2019). The calibration curves were linear with the coefficient of determination $\left(\mathrm{R}^{2}\right) 0.99$ (Figure S1-S2). An average 194 recovery percentage $>85 \%$ along with repeatability $\left(\mathrm{RSD}_{\mathrm{r}}\right)$ and within-laboratory reproducibility $\left(\mathrm{RSD}_{\mathrm{wR}}\right)<20 \%$ for 195 all the substrates proved that the methods were accurate and repeatable (Table S2). The matrix effect of both fomesafen and quizalofop-ethyl was within $\pm 20 \%$ (Table S2) and the specificity of the method was also found to be acceptable as the responses of both the compounds were $<30 \%$ of the matrix matched standard at the desired retention time in control samples. The limit of quantification (LOQ) of both the molecules was $0.01 \mathrm{mg} \mathrm{kg}^{-1}$.

\section{Kinetics of dissipation of fomesafen and quizalofop-ethyl}

200 The dissipation of fomesafen in soil and soybean plant followed the biphasic DFOP kinetics (Fig. 2; Table 1). The 201 biphasic degradation of fomesafen involved rapid initial photolysis from both soil and plant surfaces in the first phase. The compound then moved gradually into the soil column or plant matrix, which increased the chance of adsorption with soil colloids or plant cellular components and thereby reduced the rate of soil microbial or chemical degradation as well as the plant enzymatic metabolism. Hence, a slower second phase of fomesafen dissipation was observed. Similarly, Walker and Bond (1977) reported that herbicides dissipated more rapidly from the soil surface than an application incorporated into the soil column. Ugare et al. (2013) reported biphasic dissipation of several

207 pesticides in plants due to adsorption with cellular components. Wu et al. (2014) reported biphasic dissipation of 208 fomesafen in soil, where the rate of degradation decreased due to increased adsorption of the molecule with time. 


\section{Effect of seasonal variation on dissipation of fomesafen}

215 The average initial concentration of fomesafen in Season I and II ranged between 0.097-0.175 and 0.110-0.190 mg

$216 \mathrm{~kg}^{-1}$ in soil (Fig. 2a) and 0.249-0.497 and 0.261-0.509 $\mathrm{mg} \mathrm{kg}^{-1}$ in soybean plant (Fig. 2b). A significant variation in

217 the persistence of fomesafen between two consecutive seasons was observed in case of both soil and soybean plant

218 (Table S3). The half-life of fomesafen was found to be lower in Season I (4.23-4.49 days in soil and 2.84-2.89 days

219 in plant) than Season II (5.42-5.62 days in soil and 3.71-3.81 days in plant) (Table 1). A report from the Health

220 Canada Pest Management Regulatory Agency (2018) described fomesafen half-life in soil may vary from less than 1

221 to more than 4 months depending on the environmental conditions under field condition. The overall shorter

222 persistence of fomesafen in Season I than Season II in our experiment was primarily due to faster rate of 223 photodegradation of the molecule from both soil and plant surface, since the average intensity of UV radiation, total

224 solar radiation and bright sunshine hour (BSSH) were observed to be much higher in Season I along with less cloud 225 coverage (UV index: 12.34, Intensity of total solar radiation: 275.42 Watt $\mathrm{m}^{-2}$, BSSH: 10 hours, cloud coverage: $22639.06 \%$ ) than Season II (UV index: 11.36, Intensity of total solar radiation: $209.24 \mathrm{Watt} \mathrm{m}^{-2}$, BSSH: 5.1 hours, cloud 227 coverage: 78.13\%) (Fig. 1). Photodegradation is reported to be the major decomposition pathway of fomesafen 228 under field condition, which readily degrades the molecule even under relatively low sunlight conditions (Ahrens 229 1994). Besides, both microbial degradation and chemical hydrolysis play an important role in fomesafen dissipation 230 (Das et al. 2020; USEPA 2006) and the rate of degradation increases with an increase in temperature. Hence, higher 231 soil temperature in Season I $\left(34{ }^{\circ} \mathrm{C}\right)$ may also have contributed to some extent to the shorter persistence of 232 fomesafen in soil by decreasing the adsorption of the molecule and augmenting the rate of dissipation as compared 233 to Season II $\left(31^{\circ} \mathrm{C}\right)$ (Fig. 1). Similarly, Rauch et al. (2007) reported that fomesafen dissipation occurs more rapidly 234 under warmer climatic conditions, while cold climatic conditions favour high concentrations.

\section{Effect of seasonal variation on dissipation of quizalofop-ethyl}

236 The average initial concentration of quizalofop-ethyl in soil ranged between $0.034-0.055 \mathrm{mg} \mathrm{kg}^{-1}$ in Season I and $2370.035-0.053 \mathrm{mg} \mathrm{kg}^{-1}$ in Season II (Fig. 3a). The half-life of quizalofop-ethyl in field soil was 1.63-1.70 days in 238 Season I and 1.66-1.83 days in Season II (Table 1). The variation in the persistence of quizalofop-ethyl in soil 239 between two consecutive seasons was found to be non-significant (Table S3). The reason underlying the fact is that 240 the deesterification of quizalofop-ethyl to quizalofop acid, which is the major metabolic pathway of aryloxy 
reported that $\mathrm{pH}$ is the key determining factor for degradation of quizalofop-ethyl in soil (Mantzos et al. 2017). Besides, Das et al. (2020) described that the rate of deesterification of quizalofop-ethyl reduces at lower $\mathrm{pH}$. The $\mathrm{pH}$

244 of the soil in our experiment was acidic i.e. 6.4 (Table S1). Hence, quizalofop-ethyl showed an overall higher persistence in our experiment with half-life of 1.63-1.83 days in soil (Table 1) than the previously reported half-life of the molecule, which was 0.55-0.68 days (EFSA 2008; Mantzos et al. 2015). (Table S3). The estimated half-life was lower in Season I (1.76-1.77 days) than Season II (1.90-1.96 days) (Table 1). The dissipation of quizalofop-ethyl in soybean plant is represented in Fig. 3b. It has already been reported that the metabolism of AOPP herbicides in tolerant crop like soybean occur through deesterification by carboxy esterase enzyme and aryl hydroxylation by cytochrome P450 monooxygenase or oxidase enzymatic system (Koeppe et al. 1990). The rate of such enzymatic degradation is highly dependent on temperature. A significant reduction of herbicidal activity was observed at higher temperature, which is due to increased metabolism of the compound (Coupland 1989). Refatti et al. (2019) also reported a $3{ }^{\circ} \mathrm{C}$ increment in temperature resulted in $30 \%$ reduction in cyhalofop-butyl activity due to constitutive upregulation of key genes responsible for detoxification of xenobiotics in higher temperature. In our experiment, higher atmospheric temperature in Season I $\left(30.1^{\circ} \mathrm{C}\right)$ (Fig. 1) thus induced an increased rate of metabolism of quizalofop-ethyl in soybean plant and thereby lower half-life than Season II (26.3 $\left.{ }^{\circ} \mathrm{C}\right)$.

\section{End-point residue analysis at harvest}

260 The interval between the herbicide application and the crop harvest was 100 days. The end-point residues of both 261 fomesafen and quizalofop-ethyl in soil and harvested soybean seed (oil and deoiled cake) were below the 262 quantifiable limit, i.e. $0.01 \mathrm{mg} \mathrm{kg}^{-1}$ (Figure S3-S4). Mandal et al. (2014) also reported that the residues of quizalofop 263 ethyl in black gram were below the quantification limit $\left(0.01 \mathrm{mg} \mathrm{kg}^{-1}\right)$ at harvest. Besides, the residues in harvested 264 crop products were also below the maximum residue limit (MRL) prescribed by the European Union i.e. $0.02 \mathrm{mg} \mathrm{kg}^{-}$

$265{ }^{1}$ for fomesafen and $0.2 \mathrm{mg} \mathrm{kg}^{-1}$ for quizalofop-ethyl. Hence, the application of the herbicide mixture in soybean crop 266 was considered safe for consumer health.

\section{Safety evaluation}

Dietary risk assessment 
The dietary risk quotient $\left(\mathrm{RQ}_{\mathrm{d}}\right)$ of fomesafen ranged between $0.010-0.212$ for adults and $0.014-0.283$ for children (Table 2). The $\mathrm{RQ}_{\mathrm{d}}$ of quizalofop-ethyl ranged between $0.018-0.155$ for adults and $0.025-0.207$ for children (Table

271 3). Since, the chronic $\mathrm{RQ}_{\mathrm{d}}$ of both fomesafen and quizalofop-ethyl on each sampling day were below 1 irrespective 272 of the season and dose, the application of the herbicide mixture was therefore considered to impose no long-term 273 risk of dietary toxicity. Pang and $\mathrm{Hu}$ (2020) also reported no dietary toxicity due to fomesafen application in 274 soybean.

275 Soil ecological risk assessment

276 The soil ecological risk quotients indicated that both fomesafen and quizalofop-ethyl are safe towards earthworm 277 and soil arthropods (Table 2-3). However, a high risk for fomesafen and moderate to high risk for quizalofop-ethyl 278 against green algae was observed (Table 2-3). Fomesafen has been reported to be toxic to green algae (Caquet et al. 279 2005). A moderate toxicity against green algae Pseudokirchneriella subcapitata was also reported for quizalofopethyl (PPDB 2021b). Therefore, the risk associated with soil algal population due to application of this herbicide 281 mixture can't be ignored and should be assessed extensively in different agro-climatic zones across the globe in 282 future to establish a conclusive inference.

\section{Conclusion}

284 The degradation dynamics of the herbicide mixture i.e. fomesafen $12 \%$ + quizalofop-ethyl $3 \%$ was studied in the soybean ecosystem in two succeeding seasons at two treatment doses. A significant effect of seasonal variation on the dissipation of the herbicide mixture was observed. However, the variation in persistence was observed to be nonsignificant at two treatment doses irrespective of season. The overall low persistence of both the active ingredients indicated that the formulation is safe for application in the tropical agroclimatic environment and can be used as an 289 alternative to the older molecules which in general leave considerable residues in harvested products. Both 290 fomesafen and quizalofop-ethyl showed low chronic dietary toxicity to the children as well as adults. Besides, the absence of residues at harvest concluded that the harvested soybean products can be consumed safely if the

292 formulation is applied at the recommended dose following good agricultural practices (GAP). However, the risk of 293 acute dietary toxicity was not evidenced in this study. The assessment of soil ecological risk demonstrated that the 294 herbicide mixture was safe towards earthworm and soil dwelling arthropods, whereas a high risk against soil algal 295 population needs to be attended more carefully and sorted out as the future scope of research. 


\section{Declarations}

\section{Ethics approval and consent to participate}

298 Not applicable.

299 Consent for publication

300 Not applicable.

$301 \quad$ Availability of data and materials

302 The datasets used and/or analyzed during the current study are available from the corresponding author on 303 reasonable request.

304 Competing interest

305 The authors declare that they have no competing interests.

$306 \quad$ Funding

307 No funding was received for conducting this study.

308 Authors' contributions

309 SD developed the experimental design and wrote the manuscript. DS developed and validated the analytical

310 methods. AK conducted the field experiment, collected and prepared the samples. SM performed the statistical 311 analysis and representation of the data generated. $\mathrm{AK}$ and $\mathrm{AB}$ contributed to the language editing and MK reviewed 312 the manuscript. SR supervised the whole experiment and revised the manuscript for final submission. All authors 313 read and approved the final manuscript.

\section{Acknowledgement}

315 The authors are indebted to the Export Testing Laboratory (NABL accredited ISO/IEC 17025: 2005 certified), 316 Bidhan Chandra Krishi Viswavidyalaya for providing infrastructure facilities and Crystal Crop Protection Pvt. Ltd.

317 for providing analytical reference materials and the formulation.

\section{$318 \quad$ References}

319 Ahrens WH (1994) Herbicide handbook. WSSA, Champaign, USA

320 Alves C, Costa E, Sofiatti JR, Forte CT, Winter FL, Holz CM, Kaizer RR, Galon L (2018) Effect of herbicides in 321 the oxidative stress in crop winter species. An Acad Bras Cienc 90:1533-1542. https://doi.org/10.1590/0001-

322 3765201820170482 
323

324

Caquet T, Deydier-Stephan L, Lacroix G, Le Rouzic B, Lescher-Moutoue F (2005) Effects of fomesafen, alone and in combination with an adjuvant, on plankton communities in freshwater outdoor pond mesocosms. Environ Toxicol Chem 24:1116-1124. https://doi.org/10.1897/04-228R.1

Coupland D (1989) Pre-treatment environmental effects on the uptake, translocation, metabolism and performance of fluazifop-butyl in Elymus repens. Weed Res 29:289-297. https://doi.org/10.1111/j.13653180.1989.tb00914.x

Das S, Singha D, Kundu A, Saha S, Bhattacharyya A, Roy S (2020) Effect of pH on the hydrolytic transformation of a new mixture formulation of fomesafen and quizalofop-ethyl in water. Bull Environ Contam Toxicol. https://doi.org/10.1007/s00128-020-02808-x

Delcour I, Spanoghe P, Uyttendaele M (2015) Literature review: impact of climate change on pesticide use. Food Res Int 68:7-15

European Communities (2003) Technical guidance document on risk assessment. Institute for Health and Consumer $\begin{array}{lll}\text { Protection, } & \text { European } & \text { Chemicals }\end{array}$ https://echa.europa.eu/documents/10162/16960216/tgdpart1_2ed_en.pdf. Accessed 26 April 2021

European Food Safety Authority (EFSA) (2008) Conclusion regarding the peer review of the pesticide risk assessment of the active substance quizalofop-P (considered variants quizalofop-P-ethyl and quizalofop-Ptefuryl). https://efsa.onlinelibrary.wiley.com/doi/pdf/10.2903/j.efsa.2009.205r. Accessed 28 April 2021

FOrum for the Co-ordination of pesticide fate models and their USe (FOCUS) (2006) Guidance document on estimating persistence and degradation kinetics from environmental fate studies on pesticides in EU registration. Report of the FOCUS work group on degradation kinetics, EC document reference Sanco/10058/2005 version 2.0 . https://esdac.jrc.ec.europa.eu/public_path/projects_data/focus/dk/docs/finalreportFOCDegKinetics.pdf. Accessed 19 April 2021

Gharde Y, Singh PK, Dubey RP, Gupta PK (2018) Assessment of yield and economic losses in agriculture due to weeds in India. Crop Prot 107:12-18. https://doi.org/10.1016/j.cropro.2018.01.007

Gluhar S, Kaurin A, Grubar T, Prosen H, Lestan D (2019) Dissipation of mecoprop-P, isoproturon, bentazon and Smetolachlor in heavy metal contaminated acidic and calcareous soil before and after EDTA-based remediation. Chemosphere 237:1-8. https://doi.org/10.1016/j.chemosphere.2019.124513 
Health Canada Pest Management Regulatory Agency (2018) Fomesafen and its associated end-use products. Proposed re-evaluation decision - PRVD2018-15. http://publications.gc.ca/collections/collection_2018/schc/h113-27/H113-27-2018-15-eng.pdf. Accessed 28 April 2021

Janaki P, Bhuvanadevi S, Dhananivetha M, Murali Arthanari P, Chinnusamy C (2018) Persistence of quizalofop ethyl in soil and safety to ground nut by ultrasonic bath extraction and HPLC-DAD detection. J Res Weed Sci 1:1-12

Koeppe MK, Anderson JJ, Shalaby LM (1990) Metabolism of $\left[{ }^{14}\right.$ C]quizalofop-ethyl in soybean and cotton plants. J Agric Food Chem 38:1085-1091. https://doi.org/10.1021/jf00094a039

Mandal K, Sahoo SK, Battu RS, Singh B (2014) Estimation of quizalofop ethyl residues in black gram (Vigna mungo L.) by gas liquid chromatography. Bull Environ Contam Toxicol 92:115-118

Mantzos N, Antonopoulou M, Katsoulakou S, Hela D, Konstantinou I (2017) Soil degradation of metazachlor and quizalofop-p-ethyl herbicides on TLC plates under natural solar light and dark conditions. Int J Environ Anal Chem 97:606-622. https://doi.org/10.1080/03067319.2017.1337109

National Institute of Nutrition (2011) Dietary guidelines for Indians - a manual. Indian Council of Medical Research. https://www.nin.res.in/downloads/DietaryGuidelinesforNINwebsite.pdf. Accessed 26 April 2021

Pesticide Properties DataBase (PPDB)

Fomesafen. University of

Hertfordshire. https://sitem.herts.ac.uk/aeru/ppdb/en/Reports/355.htm. Accessed 26 April 2021 https://sitem.herts.ac.uk/aeru/ppdb/en/Reports/583.htm. Accessed 26 April 2021 
Accessed 19 April 2021

\section{$404 \quad$ Figure captions} $05-168.1$

Rauch BJ, Bellinder RR, Brainard DC, Lane M, Thies JE (2007) Dissipation of fomesafen in New York state soils and potential to cause carryover injury to sweet corn. Weed Technol 21:206-212. https://doi.org/10.1614/wt-

Refatti JP, de Avila LA, Camargo ER, Ziska LH, Oliveira C, Salas-Perez R, Rouse CE, Roma-Burgos N (2019) High $\left[\mathrm{CO}_{2}\right]$ and temperature increase resistance to cyhalofop-butyl in multiple-resistant Echinochloa colona. Front Plant Sci 10:1-11. https://doi.org/10.3389/fpls.2019.00529

Rhodes LA, McCarl BA (2020) An analysis of climate impacts on herbicide, insecticide, and fungicide expenditures. Agronomy 10:1-12. https://doi.org/10.3390/agronomy10050745

RStudio Team (2020) RStudio: integrated development for R. RStudio, Inc., Boston, MA. http://www.rstudio.com/. Accessed 19 April 2021

SANTE (2019) Analytical quality control and method validation procedures for pesticide residues analysis in food

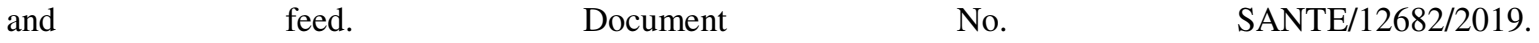
https://ec.europa.eu/food/sites/food/files/plant/docs/pesticides_mrl_guidelines_wrkdoc_2019-12682.pdf. Accessed 22 April 2021

Ugare B, Banerjee K, Ramteke SD, Pradhan S, Oulkar DP, Utture SC, Adsule PG (2013) Dissipation kinetics of forchlorfenuron, 6-benzyl aminopurine, gibberellic acid and ethephon residues in table grapes (Vitis vinifera). Food Chem 141:4208-4214. https://doi.org/10.1016/j.foodchem.2013.06.111

United States Environmental Protection Agency (USEPA) (2006) Registration review ecological risk assessment problem formulation for: fomesafen. http://www.fluoridealert.org/wp-content/pesticides/docket/EPA-HQOPP-2006-0239-0007.pdf. Accessed 28 April 2021

Walker A, Bond W (1977) Persistence of the herbicide AC 92,553, N-( 1-ethylpropyl)-2,6-dinitro-3,4-xylidine, in soils. Pestic Sci 8:359-365

Wu X, Xu J, Dong F, Liu X, Zheng Y (2014) Responses of soil microbial community to different concentration of fomesafen. J Hazard Mater 273:155-164. https://doi.org/10.1016/j.jhazmat.2014.03.041 
405 Fig. 1 The temporal patterns of maximum, minimum and soil temperature; maximum and minimum relative 406 humidity (RH I and RH II); cloud octa; bright sunshine hours; UV index and total solar intensity in Season I (a) and 407 Season II (b)

408 Fig. 2 Dissipation of fomesafen in soil (a) and soybean plant (b) applied at two treatment doses (T1 and T2) in 409 Season I and Season II

410 Fig. 3 Dissipation of quizalofop-ethyl in soil (a) and soybean plant (b) applied at two treatment doses (T1 and T2) in 411 Season I and Season II 
Figures
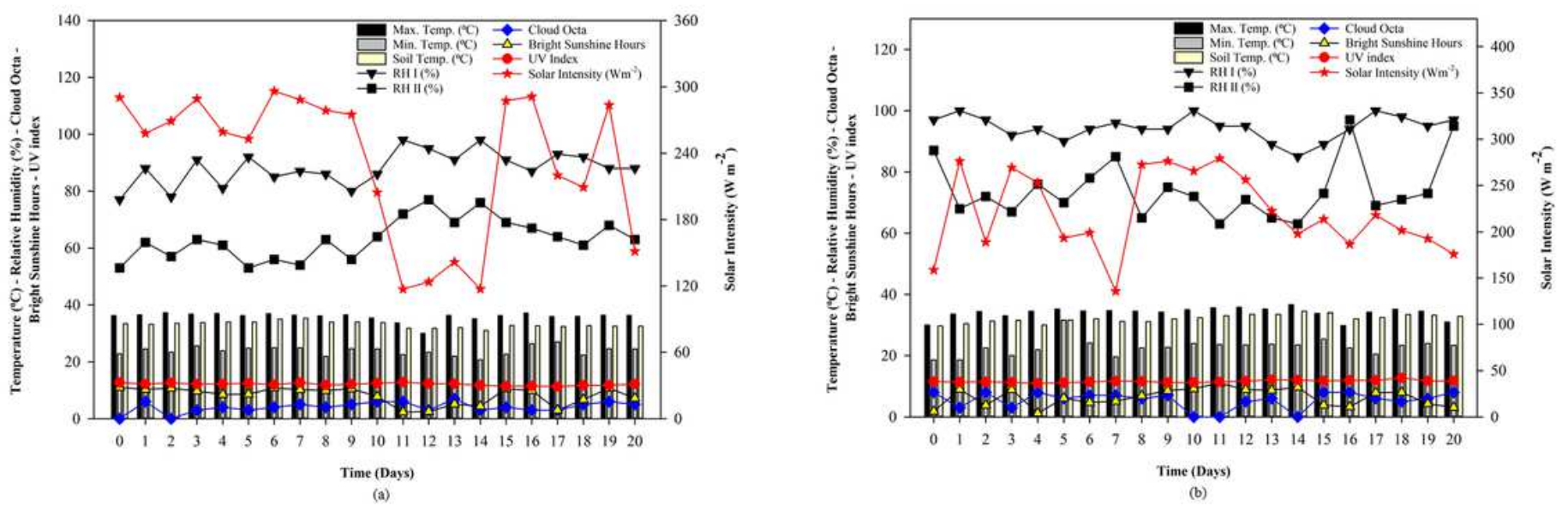

\section{Figure 1}

The temporal patterns of maximum, minimum and soil temperature; maximum and minimum relative humidity (RH I and RH II); cloud octa; bright sunshine hours; UV index and total solar intensity in Season I (a) and Season II (b) 

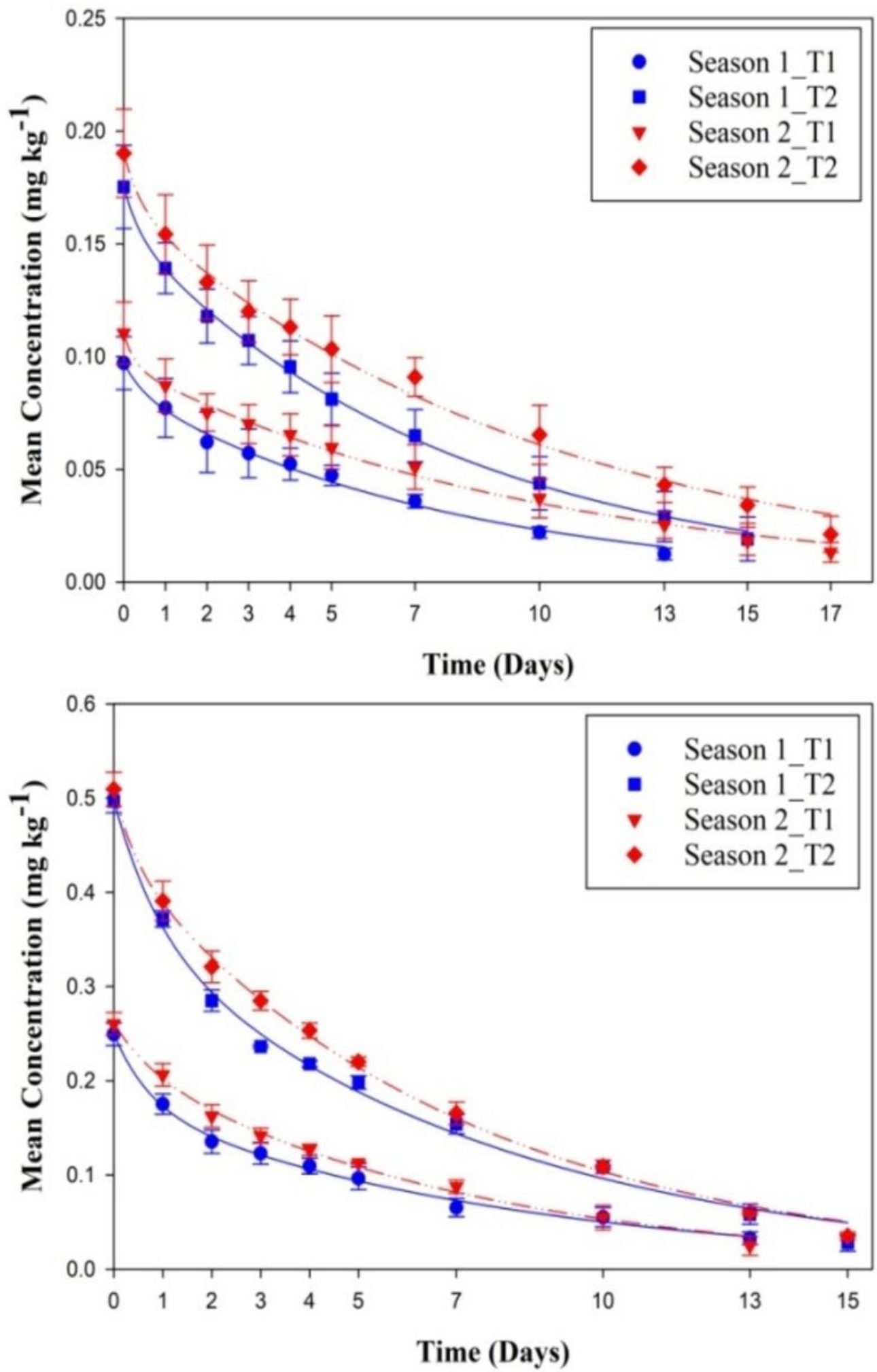

Figure 2

Dissipation of fomesafen in soil (a) and soybean plant (b) applied at two treatment doses (T1 and T2) in Season I and Season II 

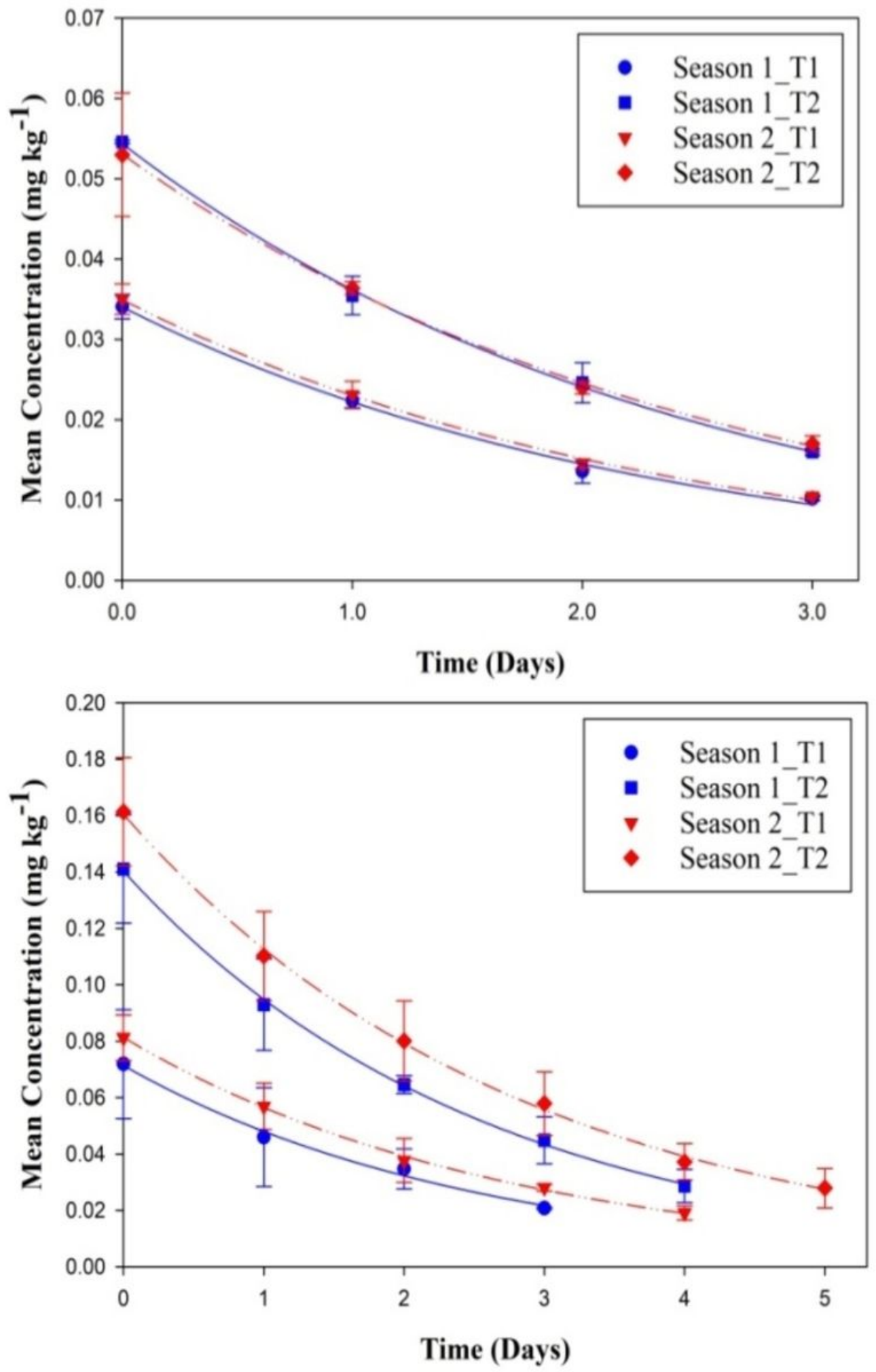

Figure 3

Dissipation of quizalofop-ethyl in soil (a) and soybean plant (b) applied at two treatment doses (T1 and T2) in Season I and Season II

\section{Supplementary Files}


This is a list of supplementary files associated with this preprint. Click to download.

- ESM1.pdf 